\title{
Hipotēkas ietekme uz prasijumu noilgumu Latvijas civiltiesībās
}

\author{
Ph.D. Aleksandrs Fillers \\ Rìgas Juridiskā augstskola, Rìgas Stradiña universitāte, Latvija \\ Aleksandrs.Fillers@rgsl.edu.lv
}

\section{Kopsavilkums}

Saskaṇā ar Civillikuma 1907. pantu zemesgrāmatās ierakstītas saistību tiesības nav pakḷautas noilgumam. Minētā norma raisa jautājumu, vai arī tāda saistību tiesība, kas ir nodrošināta ar zemesgrāmatā reǵistrētu hipotēku, nav pakḷauta noilgumam. Savā praksē Augstākā tiesa ir lēmusi, ka 1907. pants neattiecas uz šādām saistību tiesībām. Proti, tiesas ieskatā arī ar hipotēku nodrošinātās saistību tiesības ir pakḷautas noilgumam.

Rakstā Civillikuma 1907. panta saturs tiek analizēts, izmantojot sistēmisko un vēsturisko interpretācijas metodi, kā arī pirmskara doktrīnas atziṇas. Autors secina, ka vismaz gadījumos, kad pats parādnieks ir arī hipotēkas devējs, hipotēkas nodibināšana pār parādnieka īpašumu pārtrauc noilguma termiṇa tecējumu attiecībā uz nodrošināto prasījumu.

Atslēgvārdi: hipotēka, noilgums, ḳilas tiesība, saistìbu tiesības.

\section{levads}

Latvijas Civillikuma [1] (turpmāk - CL) 1907. pantā ir noteikts, ka "[n]oilgumam nav pakḷautas zemesgrāmatās ierakstītas saistību tiesības, izṇemot no tādām tiesībām izrietošas blakus tiesības, kam iestājies termiņ̌̌”. Acīmredzot minētā CL norma raisa jautājumu, vai arī ar hipotēku nodrošinātie prasījumi nav pakḷauti noilgumam, proti, vai saistību tiesība, kuru nodrošina hipotēka, neizbeigsies arī tad, ja kreditors nav savu tiesību izmantojis likumā noteiktā noilguma termiṇā? Šāds jautājums nav tikai teorētisks, tam ir arī praktiska nozīme. Uz to norāda 2017. gada 4. jūlija spriedums lietā Nr. C20229814 (SKC248/2017) (turpmāk - Spriedums) [2], kurā Augstākajai tiesai bija jālemj, vai CL 1907. pants ir piemērojams arì ar hipotēku nodrošinātiem prasījumiem. Savā argumentācijā Augstākā tiesa norādīja, ka CL 1907. pantam ir nozīme tikai tajos gadījumos, kad likumā tieši noteikts (piemēram, 2057., 2063. un 2126. pantā), ka zināmu 
saistību var ierakstìt zemesgrāmatā. Tādējādi tiesas skatījumā CL 1907. pants neesot piemērojams ar hipotēku nodrošinātiem prasījumiem un šādi prasījumi esot pakḷauti noilgumam.

N̦emot vērā, ka, pēc autora domām, Augstākās tiesas pieeja nav atzīstama par pareizu, raksta mērḳis ir pamatot, ka CL 1907. pants ir piemērojams arī ar hipotēku nodrošinātiem prasijumiem. Te gan jānorāda, ka Augstākajai tiesai, gatavojot Spriedumu, bija jāizvērtē gadījums, kad ieḳīātais nekustamais īpašums piederēja trešajai personai, nevis pašam parādniekam. Taču Augstākās tiesas atziņas ir formulētas tādējādi, ka tajās netiek nošķirti gadījumi, kad lietu ieķīlā parādnieks vai trešā persona. Rakstā autors analizējis tipiskāko ḳilas gadījumu, kad tieši parādnieks ir ieḳilājis ḳîlas objektu. Arī šī raksta secinājumi ir attiecināmi tieši uz gadījumu, kad lietu ieḳilā pats parādnieks.

Darbā ir izmantota vēsturiskā metode, lai sniegtu ieskatu attiecīgo CL normu vēsturiskajā attīstībā, un analītiskā metode, ar kuras palīdzību tika analizēti dažādu autoru viedokḷi par ḳīlas un noilgumu institūtu mijiedarbību.

\section{Augstākās tiesas spriedums un tajā izmantotā argumentācija}

Augstākā tiesa izskatīja jautājumu, vai ar hipotēku nodrošinātie prasījumi ir pakḷauti noilgumam. İsumā lietas izklāsts: 2006. gadā kāda Latvijas banka bija noslēgusi aizdevuma līgumu ar fizisku personu. Parādnieka saistību nodrošināja trešā persona ar savu nekustamo īpašumu. 2010. gada jūnijā parādnieks pārstāja pildìt savas saistības par aizdevuma atmaksu un procentu maksājumiem, bet tā paša gada novembrī aizdevēja vienpusēji atkāpās no aizdevuma līguma un pieprasīja parādniekam un trešajai personai dzēst saistības. Šo pieprasijumu parādnieks un trešā persona ignorēja. Nākamo atgādinājumu parādnieks un trešā persona saṇēma jau 2014. gadā. Tajā pašā gadā banka cēla prasību pret parādnieku par saistības izpildi un pret ḳîlas devēju par ieḳilātā nekustamā ipašuma pārdošanu izsolē.

Ar Liepājas tiesas 2014. gada 9. decembra spriedumu prasība tika apmierināta. Savukārt ar 2015. gada 5. maija spriedumu Kurzemes apgabaltiesas Civillietu tiesas kolēgija prasību noraidīja. Apelācijas tiesa pamatoja savu spriedumu ar noilgumu. Tiesa norādīja, ka komercdarījumi noilgst trīs gadu laikā un šajā gadījumā termin, š sācis ritēt no 2010. gada 15. novembra, kad aizdevēja atkāpusies no līguma. Tādējādi termin̦š esot beidzies 2013. gada 15. novembrī, taču prasība tiesā celta 2014. gada 14. jūlijā. Savukārt 2014. gada 15. aprīḷa Latvijas bankas brīdinājums parādniekam un trešajai personai neesot pārtraucis un apturējis noilgumu, jo tas nosūtīts pēc prasības noilguma termiṇa beigām.

Aizdevējs iesniedza kasācijas sūdzību, tomēr Augstākā tiesa to noraidīja, atzīstot, ka saskaṇā ar 1907. pantu noilgumam nav pakḷautas tikai zemesgrāmatās ierakstītas saistïbu tiesības. Savukārt hipotēka ir lietu tiesība uz lietu, no kuras kreditors var apmierināt saistībtiesisko prasījumu. Pats fakts, ka šāda lietu tiesība nodrošina saistību tiesību, 
nemainot ḳilas liettiesisko dabu. Turklāt ar ierakstu zemesgrāmatā tiek nodibināta hipotēka kā lietu tiesība, bet šādam ierakstam nav ietekmes uz saistību tiesības spēku. Līdz ar to Augstākās tiesas ieskatā 1907. pantam ir nozīme tikai tajos gadỉjumos, kad likums tieši nosaka (piemēram, 2057., 2063. un 2126. pantā), ka zināmu saistību var ierakstīt zemesgrāmatā.

Pamatojot savus secinājumus, Augstākā tiesa plaši analizēja Vladimira Bukovska grāmatu "Civīlprocesa mācību grāmata" [4]. Jānorāda, ka šajā grāmatā ir aplūkots civilprocess un ka šì iemesla dēl diez vai tā ir pats vērtīgākais avots CL 1907. panta interpretācijai. Tomēr vēl būtiskāks ir apstāklis, ka arī šajā Bukovska grāmatā teikto Augstākā tiesa izprata kḷūdaini. Pirmkārt, Augstākā tiesa norādīja, ka Bukovskis savā grāmatā apspriež specifisku situāciju, kurā pastāvēja divu nedēḷu termiṇš, kurā kreditoriem bija jāpiesakās parādnieka mantas izsolei, jo pretējā gadījumā vin,u prasījumi noilgtu. Šis apsvērums bija par pamatu tiesai atzìt, ka Bukovska secinājumi neesot tieši piemērojami CL 1907. panta interpretācijai. Taču šāds uzskats ir kḷūdains, jo Bukovskis norādīja, ka "hipotekārie prasījumi skaitās par publiskiem un nenoilgst (Civīllik. 1597. un 3636. p.)”. [4, 654] Šis ir skaidrs apgalvojums, kas autora skatījumā nevar tikt attiecināts tikai uz kādu specifisku situāciju saistībā ar mantas izsoli. Turklāt Bukovkis atsaucās uz Baltijas vietējo likumu kopojuma (turpmāk - BVLK) 1597. un 3636. pantu, kuros nebija ne vārda par jebkāda veida izsolēm. Tieši pretēji - tie bija formulēti kā vispārīgas privāttiesību normas.

Turklāt Augstākā tiesa uzsvēra, ka Bukovska secinājumi ir pamatoti arī ar BVLK 1597. pantu. Šajā normā bija teikts, ka "[h]ipotēkas dzēš pēc tiem pašiem noteikumiem, kādi norādīti visām kịlas tiesībām (1414. un turpm. p.), tikai ar atšḳirību, ka noilgums uz hipotēkām neattiecas" [5, 211]. Līdz ar to Augstākā tiesa secināja, ka Bukovskis runāja tieši par hipotēkas, nevis prasījuma noilgumu. Šāda logika ir nepareiza. Pirmkārt, Bukovskis grāmatas tekstā norādīja, ka hipotekārie "prasījumi" nenoilgst. Otrkārt, patiešām BVLK 1597. pantā runa bija par pašas hipotēkas nenoilgšanu, nevis nodrošinātā prasījuma nepakḷaušanos noilgumam. Tomēr apstāklim, ka BVLK 1597. pantam saturiski identiska norma nav iekḷaut CL, nevar būt tāda nozīme, ka CL kontekstā hipotekārie prasījumi noilgtu, jo šādiem prasijumiem ir piemērojams CL 1907. pants, kas saturiski ir identisks BVLK 3636. pantam. Treškārt, pamatojot savu pozīciju, Bukovskis tieši atsaucās arī uz BVLK 3636. pantu, kurā savukārt noteikts, ka zemesgrāmatā ierakstìtas saistības nav pakḷautas noilgumam. Līdz ar to var atzìt, ka Augstākās tiesas mēgeinājums interpretēt Bukovska tekstu nav bijis veiksmīgs, tiesas argumentācija ir nepārliecinoša, tāpēc būtu vajadzīga CL 1907. panta dziḷāka izpēte.

\section{leskats CL 1907. panta tapšanas vēsturē}

CL 1907. panta pamatā ir BVLK 3636. pants, kurā bija noteikts, ka "[n]oilgums neattiecas uz zemes grāmatās ievestām prasījumu tiesībām, izṇemot no tādiem prasījumiem izrietošas blakus tiesības, kā, piemēram, procentus un citas tamlīdzīgas saistības, kam iestājies termin, š” $[5,491]$. Aleksandrs Nolde ir izdarīis pien,ēmumu, ka šis likuma 
normas teksts ticis pārṇemts no Saksijas Civillikuma 151. panta [14, 612], kurā teikts, ka nenoilgst prasījumi no gimenes stāvokḷa, kopīga ỉpašuma dalīšanas, robežu noteikšanas un zemes un hipotēku registros (grāmatās) ierakstītām tiesībām, izṇemot prasījumus par procentu maksājumiem un citas blakus tiesības, kurām jau iestājies termiṇš [7, 34]. ${ }^{1}$ Par to, ka šì likuma norma aptvēra ar hipotēku nodrošinātas saistības, liecina tā paša likuma 462. pants, kurā ir precizēts, ka hipotēku reǵistrā ierakstīti prasījumi nav pakḷauti noilgumam. Šajā likuma normā ir precizēts, ka attiecībā uz periodiskiem pienākumiem un pienākumu maksāt procentus, kuriem ir iestājies termiṇš, nav izmantojamas ḳilas tiesības, ja tie ir noilguši $[7,91] .^{2}$

Tādējādi ir pamats uzskatīt, ka BVLK sastādītāji BVLK 3636. panta tekstu ir pārñēmuši no Saksijas Civillikuma, kurā analog̣iska norma noteica, ka ar hipotēku nodrošināti prasījumi nav pakḷauti noilguma ietekmei. Šādu interpretāciju apstiprina arī virkne pirmskara avotu.

\section{Pirmskara literatūrā rodamais viedoklis}

Pirms vērst lasītāja uzmanību uz pirmskara literatūrā dominējušo viedokli, jāpalūkojas plašāk uz BVLK un CL normām, kurās ir runa par kịlas tiesību un noilguma mijiedarbību. Šādas normas ir vairākas. Pirmkārt, jau minētais BVLK 3636. pants un CL 1907. pants. Taču BVLK bija arī jau minētais 1597. pants, kurā bija teikts, ka "[h]ipotēkas dzēš pēc tiem pašiem noteikumiem, kādi norādīti visām kịlas tiesībām (1414. un turpm. p.), tikai ar atšķirību, ka noilgums uz hipotēkām neattiecas" [5, 211]. Šobrīd CL 1379. pantā ir noteikts, ka "[h]ipotēkas dzēš pēc tiem pašiem noteikumiem, kādi norādīti visām ķīlas tiesībām (1309. un turpm. p.)”.

Papildus tam BVLK bija arī 1422. un 1423. panti. BVLK 1422. pantā bija noteikts, ka "[a]r noilgumu ḳilas tiesība izbeidzas, ja trešā persona, nezinādama par lietas ieḳīlājumu, iegūst to par īpašumu kā brīvu ar ieilgumu [..]” [5, 196-197]. Taču šĩs likuma normas piezīmē bija norādīts, ka tā neattiecas uz zemesgrāmatā ierakstìtām hipotēkām. BVLK 1423. pantā bija teikts: “[..] ja kịlas ñēmējs likumiskā noilguma laikā neizlieto savu kịlas tiesību, cel̦ot prasību tiesā, viṇam izbeidzas prasības tiesiiba un līdz ar to arī ķīlas tiesība" [5, 197]. Arī šim pantam bija pievienota piezīme: "Šis noteikums neattiecas ne uz hipotēkām, ne uz rokas kịlām, ja vien ḳilas ṇēmējs ḳīlu nav izlaidis no savām rokām" [5, 197]. Identiska norma, kurā būtu pieminēta hipotēka, nav ietverta CL.

1 Saksijas Civillikuma 151. panta pilns teksts vācu valodā: "Unverjährbar sind Klagen auf Familienzustände, auf Theilung einer Gemeinschaft an Sachen, auf Feststellung von Grenzen und auf im Grund- und Hypothekenbuche eingetragene Rechte, mit Ausnahme der Ansprüche auf verfallene Zinsen und verfallene andere Leistungen als Nebengegenstände."

2 Saksijas Civillikuma 462. panta teksts vācu valodā: "Eine eingetragene Forderung kann auf Grund einer Verjährung nicht gelöst werden. Wegen verfallener wiederkehren den Leistungen und verfallener Zinsen jeder Art kann, wenn die Klage darauf verjährt ist, ein Pfandrecht nicht mehr geltend gemacht werden." 
Bukovska komentāri BVLK 3636. pantam tieši neskar šajā rakstā apskatāmo jautājumu [12, 1559-1560]. Satura ziṇā daudz plašāks ir 1597. panta [11, 647-648] komentārs, kurā Bukovskis citē Karlu Erdmanu. Erdmans savukārt norādijja, ka noilgums nav piemērojams zemesgrāmatā ierakstītam prasījumam, kuru nodrošina hipotēka $[9,487]$. Turklāt, izsakot šo secinājumu, viņš tieši atsaucas uz BVLK 3636. pantu [9, 487]. Ieraksts zemesgrāmatā pārtraucot pat iesāktu noilguma termina tecējumu $[9,487]$. Turpretim blakus prasījumi (tostarp procenti un līgumsods) ir pakḷauti noilgumam. Izñēmums ir gadījumā, ja šādi blakus prasījumi tiek kapitalizēti un ierakstīti zemesgrāmatā kā patstāvīgs parāds, tad arī tie ir izṇemti no noilguma darbības [9, 487].

Arī citi avoti apstiprina viedokli, ka zemesgrāmatā ierakstìta ar hipotēku nodrošināta saistība nenoilgst. Tā Lucaus savā pētījumā par noilguma institūtu Baltijas tiesībās norāda, ka BVLK 3636. pants aptver saistỉbas, kas izriet no ḳīlas līgumiem, kuri ir ierakstīti zemesgrāmatā [10,265]. Visbeidzot Sinaiskis norāda, ka pats prasijums un arī ķìlas tiesība beidzas, ja kreditors nokavē termiṇu prasības celšanai tiesā [15, 101]. Tomēr šis noteikums neesot attiecināms uz zemesgrāmatā ierakstītiem prasījumiem, kā arī rokas ḳīlām, ja vien kịlas ņēmējs neizlaiž ḳilas objektu no savām rokām [15, 101]. Taisnības labad ir jānorāda, ka Sinaiskis gan atsaucas vienīgi uz piezìmi pie BVLK 1423. panta.

Raksta tapšanas gaitā neizdevās atrast kādu pirmskara avotu, kurā būtu tieši norādìts, ka zemesgrāmatā ierakstīta hipotekāra saistību tiesība būtu pakḷauta noilgumam. Tieši pretēji - jau iepriekš norādītie doktrinālie avoti ḷauj secināt, ka pirmskara literatūrā dominēja viedoklis, ka šādi prasijumi nav pakḷauti noilgumam saskaņā ar BVLK 3636. pantu. Citas likuma normas (BVLK 1423. un 1597. pants) tikai papildus apstiprināja, ka arì pati hipotēkas prasība nav pakḷauta noilgumam, kas liekas pašsaprotami, bet pēc būtības tiesisko režìmu neietekmēja.

\section{Civillikuma sistēmiskā analīze}

CL ir sarežgìita likuma normu sistēma, un tā interpretācijas māka bieži slēpjas spējā no atsevišķām, visā likumā "izmētātām" normām izsecināt vienotu principu un pēc tam to izmantot, lai izprastu atsevišķu normu saturu. Lai pareizi izprastu CL 1907. panta tvērumu, to vajadzētu analizēt kopsakarībā ar citām CL normām. Proti, CL 1361. pantā ir noteikts, ka ar noilgumu neizbeidzas ne prasījums, kas nodrošināts ar rokas kīlu, ne kịlas tiesība, ja vien kịlas ṇēmējs ḳillu nav izlaidis no savām rokām. Šai normai ir būtiska nozīme, interpretējot CL 1907. pantu.

Pirmkārt, šajā pantā ir noteikts princips: tik ilgi, kamēr ķīlas objekts ir kreditora varā, nedz prasījums, nedz pati šì tiesība nenoilgst (šì principa teleologiskais pamatojums sniegts raksta turpinājumā). Otrkārt, hipotēka ir rokas ḳilas analogs, kurā faktisko varu pār lietu atvieto ieraksts zemesgrāmatā. Tātad pēc visiem log̣ikas likumiem šādam principam būtu jāattiecas arī uz hipotēku, jo nebūtu saprotams, kāpēc hipotekārais kreditors, kurš būtu aizsargājams (vismaz) tāpat kā rokas ḳilas kreditors, nebaudītu šādu 
aizsardzību. Līdz ar to CL 1361. pants ir vai nu jāpiemēro pēc analogijas arī ar hipotēku nodrošinātiem prasījumiem, vai arī (kas būtu saprātīgāk) jāiztulko CL 1907. pants kopsakarā ar CL 1361. pantu, proti, tādējādi, lai hipotēkas ietekme uz nodrošinātā prasījuma noilgumu būtu līdzìga rokas ḳilas ietekmei.

Tieši sistēmisks CL skatījums l̦auj atraidìt vēl vienu tēzi, kura sub silentio bija izteikta arī Augstākās tiesas Spriedumā. Analizējot Bukovska atziṇas, Augstākā tiesa piešķīa nozīmi tam, ka CL nav pārṇemts BVLK 1596. pants. Taču arī BVLK 1423. panta piezīme ir pārṇemta CL tikai dạ̦ēji. BVLK 1423. panta piezīmē tika norādīts, ka nedz rokas kịla, nedz zemesgrāmatā ierakstìta hipotēka nav pakḷauta noilgumam. Komentētāji tomēr uzsvēra, ka šajā gadījumā noilgumam nebija pakḷauta tikai pati rokas ḳilas tiesība, nevis nodrošinātais prasijums; turpretim, pamatojoties uz BVLK 3636. pantu, zemesgrāmatā ierakstītie prasijjumi nebija pakḷauti noilgumam [11, 583-584; 8, 326-327].

Pien̦emot CL, likumdevējs ir pat paplašinājis šo regulējumu. Proti, CL 1361. pantā, kurā par pamatu ir ņemtas BVLK 1423. panta piezīmes attiecībā uz rokas ḳilu, tieši noteikts, ka arī nodrošinātais prasījums nenoilgst. Tas rada pamatotu jautājumu: kādēl gan likumdevējs, paplašinot attiecīgā principa piemērošanu rokas ḳilai, to atceltu hipotēkai?

Kā varētu skaidrot to, ka CL autori nav nekur pārṇēmuši BVLK 1423. panta piezìmi attiecībā uz hipotēku? Atbilde ir ḷti vienkārša: viens no CL mērḳiem bija mazināt BVLK kazuistiku [6, 251-253]. Tà kā CL ir atrodams 1907. pants, kas aizsargā arī hipotekārus prasijumus no noilguma, tad likumdevējam nebija pamata pārņemt BVLK 1596. pantu un 1423. panta piezīmi attiecībā uz hipotēkām. Acīmredzot, ja zemesgrāmatā ierakstītie hipotekārie prasījumi nav pakḷauti noilgumam, tad nav pakḷauta noilgumam arī pati hipotēka. Lìdz ar to CL 1907. pants, tāpat kā tā pamatā izmantotais BVLK 3636. pants, spēj pilnībā aizstāt BVLK 1423. un 1596. pantu. Nepārṇemot minētās normas CL, likumdevējs ir mazinājis kazuistiku, nemainot tiesisko režīmu pēc būtības. Tomēr likumdevējam nebija šādas iespējas attiecībā uz rokas ḳīlām, jo BVLK nebija 3636. pantam identiskas normas, kas attiektos uz rokas kịlām. Šì iemesla dēl BVLK 1423. panta piezīme tika pārṇemta un pat paplašināta, bet tikai attiecībā uz rokas ḳilām, pārvēršot to par CL 1361. pantu.

\section{1361. un 1907. panta teleologiskais pamatojums}

Interesants ir jautājums, kāpēc rokas ḳila un ieraksts zemesgrāmatā novērš prasījuma noilgšanu. Skaidrojumu var rast divu autoru darbos. Pirmkārt, interpretējot BVLK 1423. panta piezīmi, Erdmans norāda, ka rokas ḳilas gadījumā pats ḳilas objekta turējuma fakts aizvieto nepieciešamību izlietot prasijumu [8, 326-327]. Bukovskis sniedz vēl izvērstāku pamatojumu, kuru tas bija pārṇēmis no Krievijas Impērijas Civillikuma projekta motīviem - kodifikācijas [11, 584], kurai bija jākḷūst par Krievijas Impērijas jauno Civillikumu, ja tā pieṇemšanu nebūtu apturējis Krievijas Impērijas sabrukums. 
Krievijas Impērijas Civillikuma projekta 388. pantā tika noteikts, ka rokas ḳilas turētājs varētu dabūt apmierinājumu no rokas ḳilas arī tad, ja pati nodrošinātā saistība jau būtu noilgusi [13, 600]. Šì panta komentāros ir norādīts, ka tas izriet no noilguma jēgas, proti, no tā, ka noilgums iestājas, ja kreditors vilcinās ar savas tiesības izmantošanu $[13,600]$. Šāda situācija nepastāvot rokas kịlas gadījumā, jo pats fakts, ka kreditors patur lietu, norādot uz viṇa nodomu izmantot ḳilas tiesību, bet apstāklis, ka viṇš necel prasību pret parādnieku, var norādìt tikai uz viṇa velmi dot parādniekam laiku saistības dzēšanai $[13,600] .^{3}$

Hipotēkas gadījumā lietas turējumu aizvieto ieraksts zemesgrāmatā. Kamēr pastāv šāds ieraksts, tikmēr, pamatojoties uz CL, kreditors izrāda nopietnu nodomu izmantot prasijumu, kuru nodrošina hipotēka. Lìdz ar to gan hipotekārie prasijumi, gan pati hipotēka kā lietu tiesība ir izṇemti no noilguma ietekmes.

Augstākās tiesas Spriedumā tika izteikta tēze: "1907. pantam ir nozīme tikai tajos gadījumos, kad likums tieši nosaka, ka zināmu saistību var ierakstīt zemesgrāmatā (piemēram, 2057., 2063. un 2126. pantā)". Tomēr savā Spriedumā Augstākā tiesa arī norādīja: "[l]ai gan, ierakstot hipotēku zemesgrāmatā, tiek norādīts arī prasījums, kuru hipotēka nodrošina, tomēr ieraksta mērḳis ir hipotēkas kā lietu tiesības nodibināšana, nevis nodrošinātā saistībtiesiskā prasījuma nodibināšana vai leǵitimācija”. Augstākās tiesas nošķīrums starp saistībām, kuras var ierakstìt zemesgrāmatā, pamatojoties uz tiešu likuma tekstu, un "neleg̣itimējošiem" ierakstiem nav pamatots. Kritērijam ir jābūt daudz vienkāršākam: vai attiecīgā saistību tiesība var tikt ierakstìta zemesgrāmatā vai ne. Piemēram, Augstākā tiesa ir pareizi lēmusi, ka patapinājums nevar tikt koroborēts [3], tātad no patapinājuma līguma izrietošajām saistībām nav piemērojams CL 1907. pants. Savukārt tās saistības, kas saskaṇā ar tiesību normām var tikt koroborētas, ir pakḷautas CL 1907. panta noteikumiem.

3 Krievijas Impērijas Civillikuma projekta 388. panta formulējums raisa jautājumu, kuram šobrīd ir vienīgi vēsturiska nozīme: ko pirmskara autori saprata ar domu, ka nenoilgst tikai pati ḳilas tiesība? Augstākās tiesas Spriedumā ar to tiek saprasts, ka ḳila izbeidzas ar nodrošināmā prasījuma noilgumu, bet tai nav sava neatkarīga noilguma. Taču Civillikuma projekta 388. pantā runa bija par to, ka, neraugoties uz nodrošināmā prasījuma noilgumu, kreditors varēja realizēt ḳilas tiesību un apmierināt savu prasījumu no ḳilas tādā apmērā, kādā tā bija nodrošināta. CL 1361. pantam ir cits pamatojums. Proti, ja jau pats ḳilas turējuma fakts liecināja, ka kreditors nav aizmirsis par savām tiesībām pret parādnieku, tad acīmredzot tas nozīmē arī to, ka viṇš nav aizmirsis tieši par nodrošināto prasījumu; ḳila ir akcesora tiesība, un ḳilas objekta atrašanās kreditora rokās nevarētu norādīt vienīgi uz kreditora velmi realizēt ḳilas tiesības; tā nesaraujami liecina arī par vēlmi paturēt tiesības izmantot savu prasījumu, jo ḳīla nemaz nevar pastāvēt bez prasījuma. Šì situācija ir līdzīga tai, kad parādnieks atzīst procentu parādu, un šāda atzǐšana pārtrauc noilgumu arī attiecībā uz galveno parādu, jo procentu atzišana prezumē visa parāda atzišsanu. 


\section{Secinājumi}

Analizējot kịlas tiesības ietekmi uz noilguma termiṇa tecējumu, rakstā ṇemti vērā vienīgi gadījumi, kad pats parādnieks ir ḳilas īpašnieks. Šādos gadījumos ir pilnīgi pamatoti uzskatît, ka fakts, ka ḳilas objekts atrodas kreditora rokās rokas ḳilas gadỉjumā vai arī pastāv ieraksts zemesgrāmatā hipotēkas gadījumā, norāda uz kreditora vēlmi realizēt savu prasījumu un vienlaikus atgādina parādniekam par pienākumu dzēst savu saistību.

Šāda logíika ir arī CL regulējuma pamatā. Proti, CL 1361. pantā ir tieši noteikts, ka ar rokas ķīlu nodrošinātais prasījums nav pakḷauts noilgumam. Tātad ḳilas objekta atrašanās kreditora varā norāda uz kreditora nodomu izlietot savu prasījumu. A fortiori tas attiecas uz gadijjumu, kad hipotekārā kreditora tiesības ir koroborētas. To papildus apstiprina apsvērums, ka hipotēka ir būtiski nozīmīgāka kredìta pieejamībai un drošībai par rokas kīlu, tādēl likumdevējam nebūtu pamata aizsargāt rokas kịlas kreditoru vairāk par hipotekāro kreditoru. To apstiprina arì CL 1907. panta vēsturiskie avoti un pirmskara doktrīna. N̦emot vērā visu iepriekš minēto, ir jāsecina, ka vismaz attiecībā uz gadỉjumiem, kad pats parādnieks ir arī rokas ḳīlas vai hipotēkas devējs, nodrošinātā saistību tiesība vairs nav pakḷauta noilgumam un iesāktais noilgums tiek pārtraukts.

\section{Impact of Mortgage on Extinctive Prescription in Latvian Civil Law}

\section{Abstract}

Pursuant to Article 1907 of the Latvian Civil Law obligations rights registered in the Land Register are not subject to extinctive prescription. The provision poses a question, whether it also applies to those obligations that are secured by a mortgage registered in the Land Register. The Latvian Supreme Court has ruled that it is not the case and that such secured obligations remain subject to the extinctive prescription. The Author of this article uses contextual and historical interpretation of the Latvian Civil Law in order to clarify the scope of Article 1907. This analysis reveals that, at least in cases where the mortgage is granted by the debtor, the registration of a mortgage, exempts the secured obligation from the effects of the extinctive prescription.

Keywords: mortgage, extinctive prescription, pledge rights, law of obligations.

\section{Avoti un literatūra}

\section{Tiesību akti}

1. Civillikums: Latvijas Republikas likums. Stājies spēkā 01.09.1992. Valdības Vēstnesis. 41, 20.02.1937. Konsolidētā redakcijā iegūts no: https://likumi.lv/doc.php?id=225418 [sk. 28.04.2020.]. 


\section{Tiesu prakse}

2. Augstākās tiesas Civillietu departamenta 2017. gada 4. jūlija spriedums civillietā Nr. C20229814, SKC248/2017.

3. Augstākās tiesas Senāta Civillietu departamenta 2012. gada 20. decembra lēmums civillietā Nr. SKC-2456/2012.

\section{Literatūra}

4. Bukovskis, V. 1933. Civīlprocesa mācību grāmata. Rīga: Autora izdevums, 654. lpp.

5. Civîllikumi: Vietējo likumu kopojuma III dal̦a. 1935. Rìga: Valters un Rapa, 196-197, 211, 491.

6. Švarcs, F. 2011. Latvijas 1937. gada 28. janvāra Civillikums un tā rašanās vēsture. Rīga: Tiesu namu aǵentūra, 251-253.

7. Das Bürgerliche Gesetzbuch für das Königreich Sachsen. 1863. Leipzig: Roßberg, 34, 91.

8. Erdmann, C. 1889. System des Privatrechts der Ostseeprovinzen Liv-, Est- und Curland. Band I: Allgemeiner Theilr. Familienrecht. Riga: N. Kymmel’s Verlag, 326-327.

9. Erdmann, C. 1891. System des Privatrechts der Ostseeprovinzen Liv-, Est- und Curland. Band II: Sachenrecht. Riga: N. Kymmel's Verlag, 487.

10. Von Lutzau, H. 1904. Die Lehre von der Klagenverjährung nach Liv-, Est- und kurländischem Privatrecht. Band I. Leipzig: Richard Wöpke, 265.

11. Bukovskii, V. 1914. Svod grazhdanskikh uzakonenii gubernii Pribaltiiskikh (s prodolzheniem 19121914 g.g. i s raziasneniiami v 2 tomakh). T. I. Vvedenie, Pravo semeistvennoe, Pravo veshchnoe $i$ Pravo nasledovaniia. Riga: G. Gempel i Ко (Буковский В. 1914. Сводъ гражданскихъ узаконений губерний Прибалтийскихъ (съ продолжениемъ 1912-1914 г. г. и съ разъяснениями въ 2 томахъ). Т. І. Введение, Право семейственное, Право вещное и Право наслеАования. Рига: Г. Гемпемь и Ко), 583-584, 647-648.

12. Bukovskii, V. 1914. Svod grazhdanskikh uzakonenii gubernii Pribaltiiskikh (s prodolzheniem 1912-1914 g. g. is raziasneniiami v 2 tomakh). T. II. Pravo Trebovanii. Riga: G. Gempel i Ko (Буковский В. 1914. СвоАъ гражАанскихъ узаконений губерний Прибалтийскихъ (съ продолжениемъ 1912-1914 г. г. и съ разъяснениями въ 2 томахъ). Т. II. Право требований. Рига: Г. Гемпемь и Ко), 1559-1560.

13. Grazhdanskoe Ulozhenie. Kniga tretia: Votchinnoe pravo. Tom vtoroi. S obiasneniiami. 1902. S.-Peterburg: Gosudarstvennaia Tipografiia (ГражАанское УАожение. Книга третья: Вотчинное право. Томъ второй. Съ объясненіями. 1902. С.-Петербургъ: Государственная Типография), 600.

14. Nolde, A. E. 1914. Ocherki po istorii kodifikatcii mestnykh grazhdanskikh zakonov pri grafe Speranskom: Vypusk 11. S.-Peterburg: Senatskaja Tipografija (Нольде А. Э. 1914. Очерки по истории кодификации местных гражданских законов при графе Сперанском: Выпускъ 11. С.-Петербургъ: Сенатская Типография), 612.

15. Sinaiskii, V. I. 1931. Osnovy grazhdankogo prava v sviazi s chastiu III svoda uzakonenii, deistvuiushchei v Latvii i Estonii. Vypusk II. Riga: Akc. o-va Valters i Rapa, (Синайский В. И. 1931. Основы гражАанского права в связи с частью III свода узаконений, действующей в $\Lambda$ атвии и Эстонии. Выпуск II. Рига: Акц. о-ва Вацьтерс и Рапа), 101. 